\title{
マルチスケール法による不均質体中のき裂先端における ミクロ応力解析*
}

\author{
高 野 直 樹*1, 奥 野 義 紘*2

\section{Microscopic Stress Analysis at Crack Tip in Heterogeneous Media by Multi-scale Method}

\author{
Naoki TAKANO*3 and Yoshihiro OKUNO \\ ${ }^{* 3}$ Department of Manufacturing Science, Osaka University, \\ 2-1 Yamada-oka, Suita-shi, Osaka, 565-0871 Japan
}

\begin{abstract}
In the development of various advanced materials by controlling their heterogeneous microstructures, there is a growing need for the multi-scale analysis. There have been many studies on the correlation between the heterogeneous microstructure and the macroscopic properties mainly using the asymptotic homogenization method with the help of the finite element method. Although the consideration of fracture origin in components such as interface crack is important in the multi-scale stress analysis, it was impossible to calculate the microscopic stress under high gradient of macroscopic strain/stress field at the crack tip. Furthermore, the representative dimension of the fracture origin lies between the microscopic scale and the macroscopic one. Hence, this paper proposes a novel three-scale computational method that employs both the homogenization method and the enhanced mesh superposition method to study the correlation among microstructure, component and fracture origin simultaneously. An equation solver for large-scale $3 \mathrm{D}$ analysis by the mesh superposition method is also presented. A demonstrative $3 \mathrm{D}$ example of porous thin film with interface crack, whose finite element model has approximately 78 thousand solid elements, is shown.
\end{abstract}

Key Words: Computational Mechanics, Finite Element Method, Multi-scale Analysis, Stress Concentration, Heterogeneous Media, Mesh Superposition, Homogenization

\section{1. 緒言}

近年, 開発が進められているシナジーセラミック ス(1) や瀻維/粒子強化複合材料に代表される先端材料 は, 不均質な微視構造を制御することにより比強度・ 比剛性などのすぐれた特性を達成している.これらの 不均質材料を用いた部材を評価する際, 界面やき裂な どの破壊因子を考える必要があるが, 破壊因子のスケ ールは部材と微視構造の中間に位置することが多 い(1). 破壊因子の一つであるき裂の進展は微視構造に 依存するし, さらに破壊因子と微視構造は部材のマク 口挙動に影響を及ぼす。よって, 不均質体の評価にお いては, 部材, 微視構造, 破壊因子の 3 スケールを同 時に考えることが重要である。

マルチスケール問題を考える上で, 漸近展開法に基 づく均質化法 ${ }^{(2)(3)}$ は, 任意の微視構造を反映したマク ロ特性の予測とミクロ・マクロ挙動解析が可能であ り, 理論的な厳密性と非線形問題への発展性 ${ }^{(4)}$ を備え

* 原稿受付 2003 年 8 月 6 日.

*1 正員, 大阪大学大学院工学研究科( 565-0871 吹田市山田 丘 2-1).

*2 大阪大学大学院工学研究科.

E-mail : takano@mapse.eng.osaka-u.ac.jp
た代表的な手法である. 工学分野で主に 1990 年以降 に盛んに研究が行われ, 繊維強化複合材料(5)(6) やコン クリート(7)などに対してミクロ・メゾ・マクロ構造 の 3 スケールを考える階層的なモデリング手法が提案 されてきた.また, 著者らは均質化法の精度検証 ${ }^{(8)(9)}$ に関する研究も行ってきた。一方, 実材料への適用に おいて,いくつかの問題点も明らかになってきた. 例 えば, 界面や表面, 局所的なき裂・ボイド・介在物な どの非周期的な箇所への均質化法の適用は不可能であ る(10). さらに, 微視構造の寸法効果を考えるべき問題 に対しても適用不可である(11). また, き裂や部材形状 によって生じる応力集中部は破壊起因となるため, 評 価・設計上において重要であるが, 応力こう配下のミ クロ応力解析には留意が必要である(12)(13).

本論文では, 部材と微視構造, それらの中間のスケ 一ルに位置する破壊因子という３スケールを考慮した 新しいマルチスケール応力解析の枠組みを構築し, 各 スケール間に適した手法として, 均質化法と拡張した 重合メッシュ法(10)(11) を併用したマルチスケール応力 解析手法を提案する. あわせて, 実用上必須となる三 次元大規模解析への障壁であった三次元重合メッシュ 法用ソルバについて検討し, 通常のパーソナルコンピ ュータで 10 万要素以上の解析を実現した. 


\section{2. 均質化法の適用限界}

均質化法によるミクロ応力解析上の問題点を, 理論 とモデリングの両面からまとめる. 理論の詳細は多く の文献(2) (4) があるので省略する．以下, $\boldsymbol{x}, \boldsymbol{y}$ はそれ ぞれマクロスケール, ミクロスケールであり, $Y$ はユ ニットセルの領域, $\boldsymbol{u}^{0}$ はマクロ変位である. 解析手 順を簡単に示すと, まず, 代表的な微視構造をモデル 化したユニットセルを用いて, 式（1）のミクロ方程式 から特性変位 $\chi$ を計算する.

$$
\int_{Y} E_{i j p q} \frac{\partial \chi_{p}^{k l}}{\partial y_{q}} \frac{\partial \bar{u}_{i}}{\partial y_{j}} d Y=\int_{Y} E_{i j k l} \frac{\partial \bar{u}_{i}}{\partial y_{j}} d Y
$$

次に, 特性変位 $\chi$ を式 ( 2)に代入し, マクロな等価物 性 $\boldsymbol{E}^{H}$ を計算する。

$$
E_{i j k l}^{H}=\frac{1}{|Y|} \int_{Y}\left(E_{i j k l}-E_{i j p q} \frac{\partial \chi_{p}^{k l}}{\partial y_{q}}\right) d Y
$$

これを用いて式 (3)のマクロ解析を行い, 最後にミク 口挙動を式 ( 4 ),（5)より計算する.

$$
\begin{aligned}
& \int_{\Omega} E_{i j k l}^{H} \frac{\partial u_{k}^{0}}{\partial x_{l}} \frac{\partial \bar{u}_{i}}{\partial x_{j}} d \Omega=\int_{\Gamma} t_{i} \bar{u}_{i} d \Gamma \\
& u_{i}(\boldsymbol{y})=\frac{\partial u_{i}^{0}}{\partial x_{j}} y_{j}-\chi_{i}^{k l} \frac{\partial u_{k}^{0}}{\partial x_{l}} \ldots \ldots \ldots \ldots . . . \\
& \sigma_{i j}=\left(E_{i j k l}-E_{i j p q} \frac{\partial \chi_{p}^{k l}}{\partial y_{q}}\right) \frac{\partial u_{k}^{0}}{\partial x_{l}} \ldots \ldots . . .
\end{aligned}
$$

式 ( 4 ) はユニットセルの変形をミクロスケールで記述 したものである(14). 式(4)，（5)において，マクロひ ずみ $\partial \boldsymbol{u}^{0} / \partial \boldsymbol{x}$ は微視領域内において一定であり, また, ユニットセルの周期性の仮定から特性変位 $\chi$ は周期 関数となる.つまり，均質化法によるミク口解析にお いて得られる変位場や応力場は周期的なものとなる.

ここで, 実材のユニットセルは有限の大きさを持つ ことを考慮したモデリングという観点から, 式 (4), ( 5 ) のマクロひずみ $\partial \boldsymbol{u}^{0} / \partial \boldsymbol{x}$ について考える. マクロ

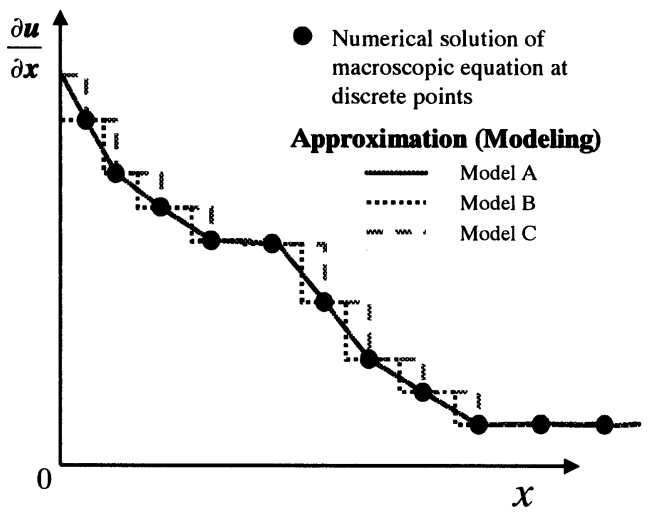

Fig. 1 Approximation of macroscopic strain field for calculation of microscopic stress
解析の結果として, マクロひずみは図 1 に示すように 要素重心やガウス点といった離散点で得られる.離散 点間のマクロひずみ場は適当な補間によりモデリング するわけだが, 例えば, 図 1 の離散点が要素のガウス 点や重心点と考えてみれば, $x=0$ のような表面上の ひずみ值の取り方にはさまざまな手法がある．Model A では, 離散点間を線形補間している. Model B で は, 離散点間が要素重心と想定し, 要素内は一定ひず みと考える手法を表す. Model C は，理論的ではな いが Model A と Model B の中間的な予測の可能性 を示している。このような種々のマクロひずみ場の処 理に基づき, 均質化法のミクロ応力解析をする際, さ らにユニットセルが有限の大きさを持つことを考慮す ると, 以下のような問題点がある。すなわち，図 2 の ようにユニットセルの大きさと位置を指定する場合に は, 図 1 のマクロひずみ場の取り方に対して, ユニッ トセル内で一定と考えるマクロひずみ值の決め方は図 2 中の○印で示すように何とおりも考えうる。ユニッ トセルの位置については, 均質化法では限定すること はできないともいえる。図 2 の状態は，例えば板やは りの曲げの問題において頻繁に発生する.さらに, マ クロひずみのこう配が大きい場合, 有限の大きさを持 つユニットセル内でマクロひずみが一定と考え, 変位 場や応力場が周期的であるという結果は正しくない. そこで, マクロひずみが非一様となる場合には, 後述 の拡張された重合メッシュ法(10)(11) を併用する.

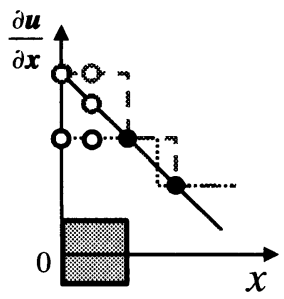

(a) Relatively large unit cell

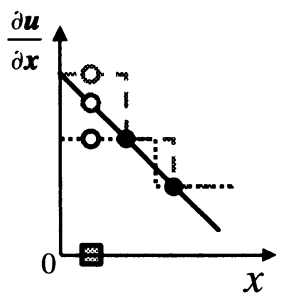

(b) Smaller unit cell

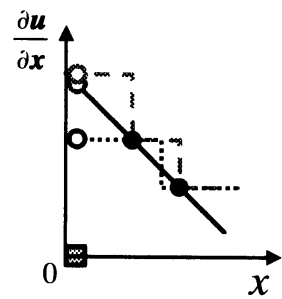

(c) Smaller unit cell at different position

Fig. 2 Determination of macroscopic strain value that is constant in microscopic region 


\section{3. 不均質体のマルチスケール 応力解析法}

$3 \cdot 1 \quad 3$ スケール問題の枠組み 上述のとおり, 不 均質体の設計・評価において, 微視的不均質構造, き 裂などの破壊因子, 部材の 3 スケールの相関が重要で ある.ここで，3 スケールを具体的に定義する。種々 の先端材料において, 図 3 に示すように微視構造はナ ノからマイクロオーダ, 部材のスケールはミリからメ ートルオーダとなり, そのスケール差は $10^{3} \sim 10^{6}$ とな る.また, 破壊因子のスケールは $10 \mu \mathrm{m} \sim 1 \mathrm{~mm}$ 程度 である場合が多く(1), その場合, 微視構造と部材の中 間のスケールに位置し, 微視構造とスケール差はたか だか $10^{2}$ 程度である。

微視構造と部材間の大きなスケール差をつなぐに は, 均質化法により, 微視構造を反映して予測したマ クロな等価物性を用いたモデリングが有効であ る(5)(9). しかし, 破壊因子を考慮するには, 2 章で述べ た問題点がある.また, $10^{2}$ 以下のスケール差といえ ども, 三次元問題ではその 3 乗の解析規模となるため, 直接的にモデリングすることは不可能である。そこで 本論文では，拡張された重合メッシュ法(10)(11)を用い て破壊因子と微視的不均質構造, および破壊因子とマ クロ部材間の相関を解析することを提案する.すなわ ち, 均質化法と拡張された重合メッシュ法を併用した 3スケール法である.なお，1章で紹介したミクロ・ メゾ・マクロを考える階層的モデリング(5)(6)では破壊 因子を考えておらず，またスケール間の寸法差も本論 文とは異なる。すなわち, 2 章で述べた問題点に対す る対策の一つとして, 著者らが以前に示した階層的モ デリング手法(5)(6) では, 重合メッシュ法(15)を併用した 要素細分割による精度改善を図ったが, 微視的不均質 構造との相関を考えたものではなく, マクロひずみこ

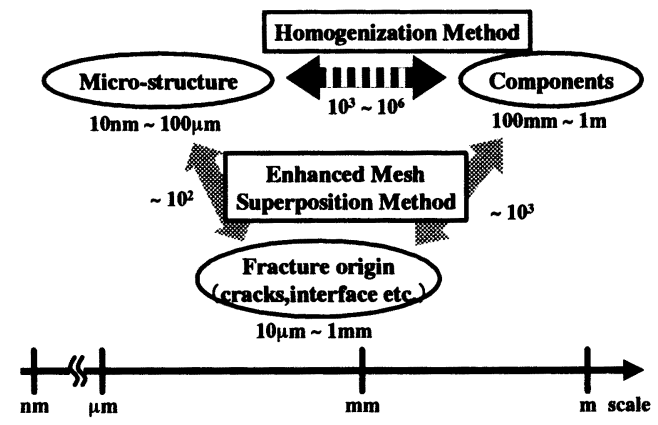

Fig. 3 Framework of three-scale stress analysis for heterogeneous media
う配下のミクロ解析としても不完全であった．本論文 で提案する 3 スケールの枠組みと計算手法は, 従来の ものとは異なる新規のものである.

\section{$3 \cdot 2$ 拡張された重合メッシュ法と大規模解析用ソ}

ルバ 重合メッシュ法は, Fish ら(15) がアダプティ ブ有限要素法の一連の研究として hp 法を発展させた $\mathrm{s}$ 法と名付けられた手法で, 当初メッシュ細分割法と して提案されたものである.その後, 均質材中のき裂 進展問題に対する有効性が示され(16), さまざまな分野 への適用が考えられている(17)(18). 著者ら(10)(11) は, 材 料の微視的かつ局所的な不均質性を考慮したマルチス ケール法として拡張し, 精度検証を行ってきた.その 適用範囲は，図 4 に示すように，ミクロき裂(19)，損傷 進展 ${ }^{(20)}$, ボイド, 介在物(10), 界面(11) のような微視領域 の周期性がない局所的不均質部や, 微視構造の寸法効 果を考慮した解析 ${ }^{(11)}$ ，および本論文で扱うき裂などの 応力集中部におけるミクロ解析と多岐にわたり，かつ 必要性が高い要因ばかりである.

拡張された重合メッシュ法の定式化は前報(11) で詳 しく述べたので以下に概要を記す。図 5 に示すよう に, 三次元弾性体領域 $\Omega$ とその境界 $\Gamma$ を考え, 境界 $\Gamma^{p}$ に表面力 $p$ が作用しているとする. マクロ領域 $\Omega$

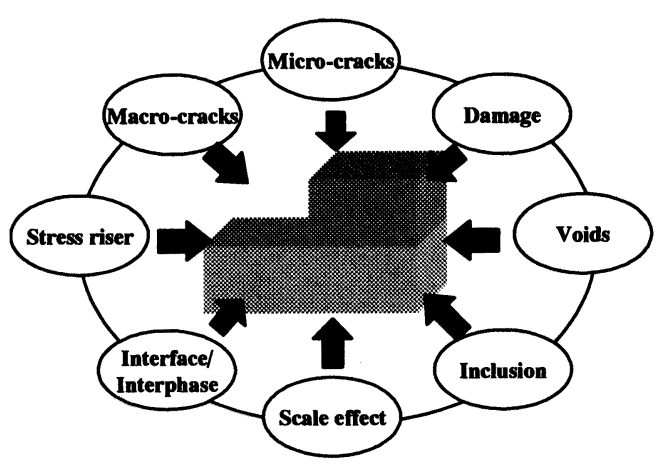

Fig. 4 Various multi-scale problems with local and non-periodic heterogeneity analyzed by enhanced mesh superposition method

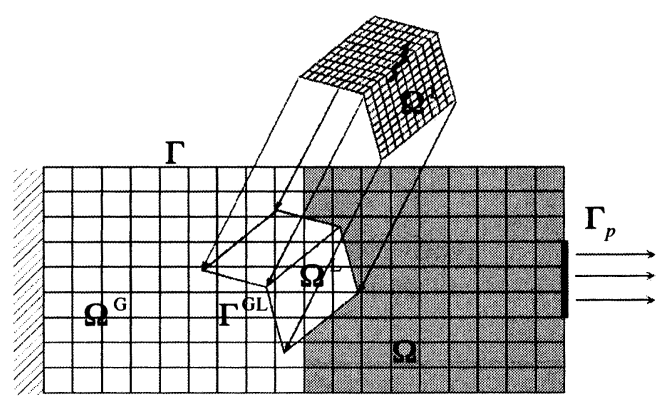

Fig. 5 Definition of analyzed domain 
内にある図 4 の注目すべき部位でミクロ領域 $\Omega^{L} \subset \Omega$ を考える. $\Omega^{G}$ を $\Omega / \Omega^{L}$ と定義する．また, $\Omega^{L}$ と $\Omega^{G}$ の境界を $\Gamma^{G L}$ と定義する. 図 5 のように, 全体領域 $\Omega$ は不均質材料の微視的不均質性を等価物性で表現 したマクロモデル，ミクロ領域 $\Omega^{L}$ では図 4 に示した 局所的不均質性を生む要因と不均質材料の微視構造を 直接表現した詳細なミクロモデルを用い, マクロモデ ルに重㸚わせる， $\Omega^{L}$ ではマクロモデルとミクロモ デルがともにあるが, 両モデルの節点の整合性に関係 なく重ねることができるため, 両モデルともに容易に 作成できるという利点がある.

拡張された重合メッシュ法の要点は, 微視的不均質 性を考慮できるようにマクロモデルとミクロモデルで 異なる構成式 (6)，（7）を使用する点にある．右上添 字の $G, L$ はそれぞれマクロモデル，ミクロモデルを 意味する．また， $\boldsymbol{B}$ は有限要素法におけるひずみ-変 位マトリックスである。

$$
\begin{aligned}
& \sigma^{G}=\boldsymbol{E}^{G}\left(\boldsymbol{B}^{G} \boldsymbol{u}^{G}-\alpha^{G} \Delta T^{G}\right) \quad \text { on } \Omega^{G} \\
& \boldsymbol{\sigma}^{L}=\boldsymbol{E}^{L}\left\{\boldsymbol{B}^{G} \boldsymbol{u}^{G}+\boldsymbol{B}^{L} \boldsymbol{u}^{L}\right. \\
& \left.-\alpha^{L}\left(\Delta T^{G}+\Delta T^{L}\right)\right\} \quad \text { on } \Omega^{L} \ldots . .
\end{aligned}
$$

ここで, 変位および温度変化を式 $(8),(9)$ のよう に定義する。

$$
\begin{aligned}
& \boldsymbol{u}=\left\{\begin{array}{l}
\boldsymbol{u}^{G} \text { on } \Omega^{G}, \Gamma^{G L} \\
\boldsymbol{u}^{G}+\boldsymbol{u}^{L} \text { on } \Omega^{L}
\end{array}\right. \\
& \Delta T= \begin{cases}\Delta T^{G} & \text { on } \Omega^{G}, \Gamma^{G L} \\
\Delta T^{G}+\Delta T^{L} & \text { on } \Omega^{L}\end{cases}
\end{aligned}
$$

マクロモデルとミクロモデルの境界 $\Gamma^{G L}$ において

$$
\boldsymbol{u}^{L}=\mathbf{0}, \Delta T^{L}=0 \quad \text { on } \Gamma^{C L}
$$

とすれば, 変位, 温度は連続である。しかし, 拡張さ れた重合メッシュ法では $\Gamma^{G L}$ で材料モデルが不連続

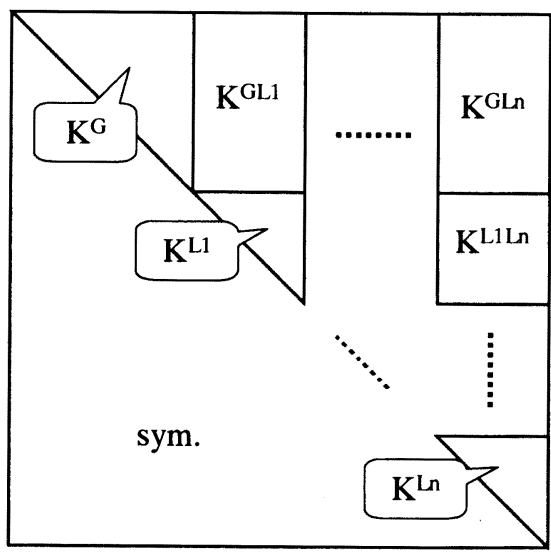

Fig. 6 Stiffness matrix by enhanced mesh superposition method
であるため, ひずみ, 応力は不連続となり, 数值解析 では $\Gamma^{C L}$ 周辺では誤差が無視できない ${ }^{(11)}$ ももちろん $\Omega^{L}$ 内部で精度上の問題はないことを確認済みであ る. 以上の式を仮想仕事の原理式に代入し，整理する と次式の剛性方程式が得られる。

$$
\left[\begin{array}{cc}
\boldsymbol{K}^{G} & \boldsymbol{K}^{G L} \\
\left(\boldsymbol{K}^{C L}\right)^{T} & \boldsymbol{K}^{L}
\end{array}\right]\left\{\begin{array}{l}
\boldsymbol{u}^{G} \\
\boldsymbol{u}^{L}
\end{array}\right\}=\left\{\begin{array}{l}
\boldsymbol{F}^{G} \\
\boldsymbol{F}^{L}
\end{array}\right\}
$$

各項の計算式は前報 ${ }^{(1)}$ に記載した (付録参照)。

最近では, 実問題への適用を想定し, マクロモデル 上に複数のミクロモデルを重ねる研究がなされてい

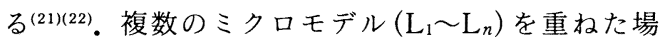
合, 剛性マトリックスは図 6 に示すようにブロック性 を有するが, 通常の有限要素法と比較してバンド幅が 大きくなり, 特に, 三次元解析では莫大な記憶容量が 必要となるという問題があった。一般的な大規模解析 ソルバである前処理付反復法を用いる研究もなされて いるが(23), 剛性マトリックスの積分精度に敏感との指 摘(23) があるほか, 著者らの検討の範囲でも対象によ り収束性が十分に保証されていない。一方, RCM 法 (Reverse Cuthill-Mckee 法)(24)によるリナンバリン グを行うことにより, 図 6 のブロック性を崩す代わり に通常の有限要素法と同等のバンド幅のマトリックス が得られることを確認した。これにより, 大規模解析 であればアウトコア・スカイライン法(ブロックスカ イライン法)(24) の適用が可能となる. 複数のミクロモ デルを重合するなどの種々の使用法に対しても，確実 に解が得られる上記ソルバは大変有用である。著者ら が確認した範囲では, 通常のパーソナルコンピュータ に例えば $60 \mathrm{~GB}$ の外付ハードディスクを備えれば約 10 万要素以上の三次元解析が可能である.

\section{4. 界面き裂を有する薄膜基板の解析}

$4 \cdot 1$ 問題設定とモデル化 本手法の適用例とし て, 図 7 に示すように界面き裂を有する貫通孔薄膜基 板のモデルを設定した. $\mathrm{SiO}_{2}$ の基板上に貫通孔が不 規則に配列している $\mathrm{TiO}_{2}$ 薄膜(気孔率： $30 \%$, 孔径： $6.2 \mu \mathrm{m})$ を考え，その界面にき裂を想定した．図 7 中 のスケールが示すように, 部材の代表寸法が $2 \mathrm{~mm}$, き裂が $0.25 \mathrm{~mm}$, 微視構造である孔径が $6.2 \mu \mathrm{m}$ であ り,スケール差は 3 章で述べた枠組みに合致してい る.

提案手法による解析手順を図 8 に示す. 薄膜のモデ リングに関しては，気孔率が比較的低いことから，不 均質に配列した貫通孔の一つをユニットセルとして取 り出し, 均質化法により等価モデルを計算する. 薄膜 部分を等価モデルに置き換え，基板を含めたマクロモ 
デルを作成する.一方, 界面き裂先端近傍の詳細挙動 を解析するためのミクロモデルを図 9 に示す.ここ で，均澌化法はマクロモデルで用いる等価モデルの導 出にのみに用い，部材の全体挙動と界面き裂先端の詳 細挙動の解析は, 均質化法を用いずに, 拡張された重 合メッシュ法を用いる. $\mathrm{SiO}_{2}, \mathrm{TiO}_{2}$ の材料定数は表 1 の值を仮定した。

図 9 には解析条件も併せて示す.マクロモデルは, 対称性加ら全体の $1 / 2$ 領域を取り出し, 規則的に要素 分割した。ミクロモデルを重合する正確な位置を図

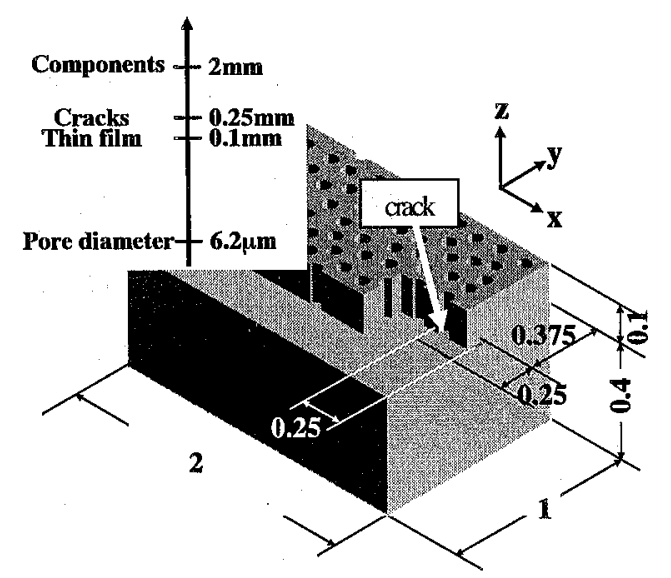

Fig. 7 Porous thin film with interface crack

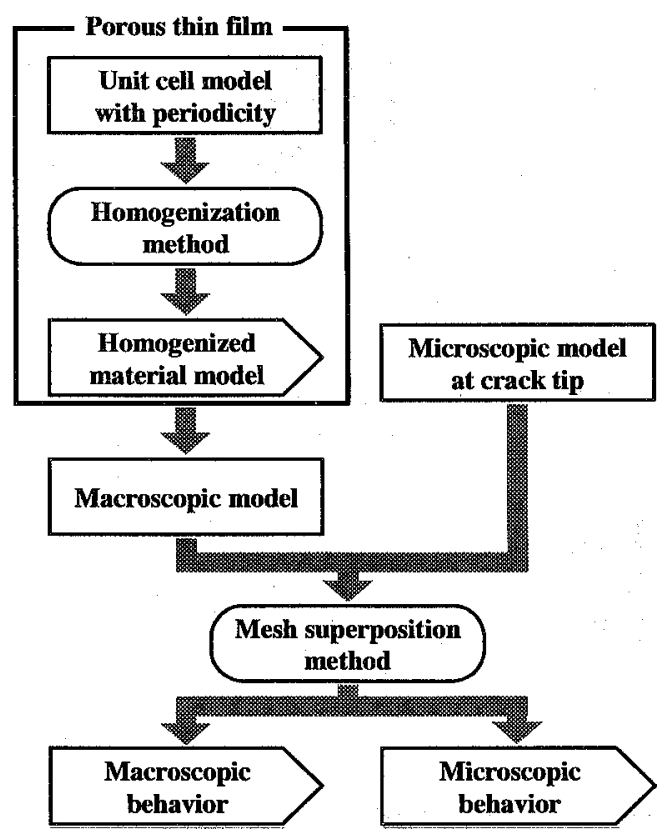

Fig. 8 Multi-scale analysis strategy for proposed method
10 に示す。図 11 はマクロモデルのみによる界面き裂 近傍の応力解析結果であるが，ミクロモデルはマクロ 応力こう配が急な微少領域 $Q^{L}$ に重ねられている。な お, 解析規模は総要素数 78080 , 総節点数 88156 であ る. その内, ミクロモデルの要素数は 46080 , 節点数 は52385である。

$4 \cdot 2$ 解析結果と考察 ミタロモデル内の応力 $\sigma_{z}$ の分布を図 12 に示す。図 12 ではミクロモデルの周辺

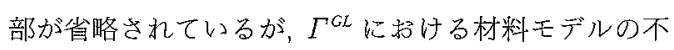
連続性からミクロモデルの境界近搒に生じる誤差に配 慮したためである。図 13 には, 図中の線上 $(x=$ $1.965, z=0.4125)$ の 名口応力 $\sigma_{z}$ の分布を示寸. 図 12,13 からミクロモデル内の応力場は非周期的である ことがわかる。このような結果は均質化法では得られ ない。また，ミクロ解析の必要性は，マクロモデルの みの解析結果よりも平均的に約 1.5 倍高い応力值を示 しつつ, 局所的には非常に高い値となっていることか

Table 1 Material properties

\begin{tabular}{|c|c|c|}
\hline & $\begin{array}{c}\text { Young'smodulus } \\
\text { (GPa) }\end{array}$ & Poisson's ratio \\
\hline $\mathrm{SiO}_{2}$ & 68 & 0.19 \\
\hline $\mathrm{TiO}_{2}$ & 228 & 027 \\
\hline
\end{tabular}

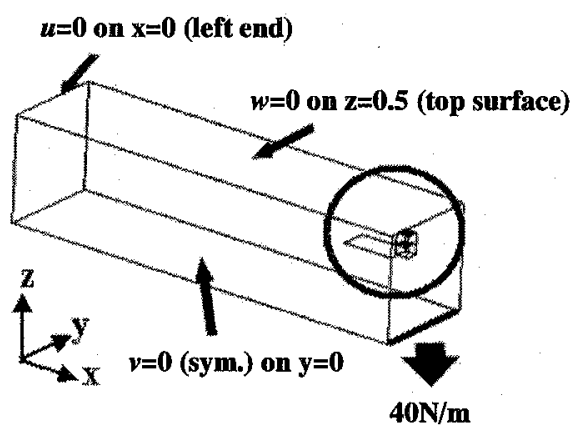

(a) Modeling strategy and boundary condition

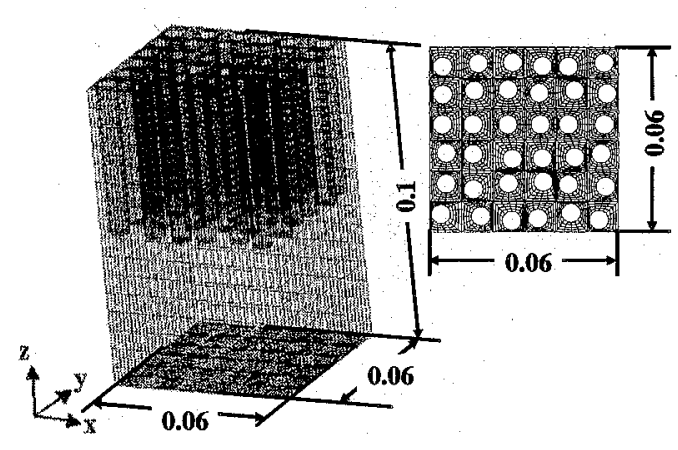

(b) Finite element mesh for microscopic model

Fig. 9 Multi-scale modeling and boundary condition 
らもわかる。き裂先端であることに加え，鿓通孔の不 規則配置も高応力発生の要因であることがわかる。

\section{5. 結言}

本論文では, 種々の不均質体の微視粠造と破壊因子, 部材それぞれの相関を考慮した新しい3スクール解析 の杵組队を示し，均質化法と拡張された重合メッシュ 法を併用したマルチスケールル手法を提案した。重合メ ッシュ法の実用化への課題であった大規模解析ソルバ について，RCM 法によるリナンバリングとアウトコ ア・スカイライン法(ブロックスカイライン法)を用い ることにより，通常のパーソナルコンピュータで 10

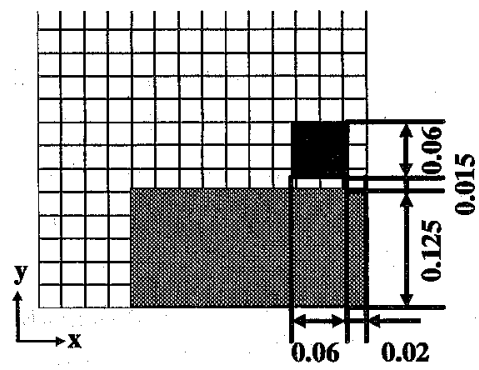

(a) $x-y$ cross section

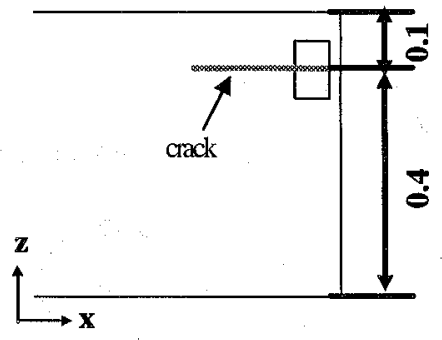

(b) $z-x$ cross section

Fig. 10 Superposition of microscopic model onto macroscopic model

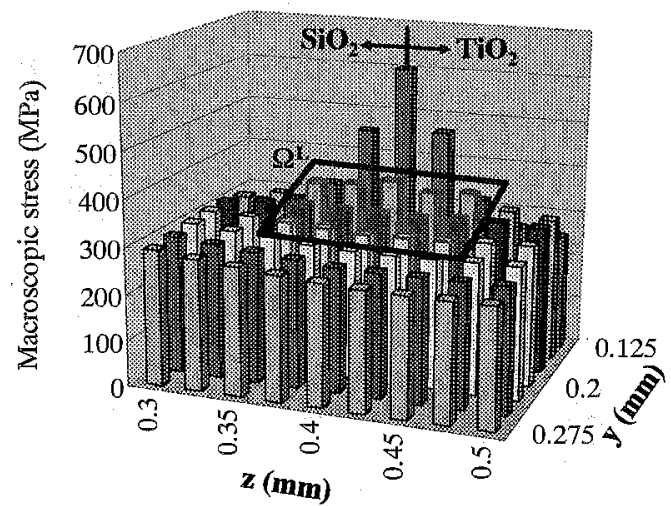

Fig. 11 Macroscopic stress field near interface crack
万要素以上の三次元解析を可能とした。また，均質化 法単独では不可能であったき裂先端におけるマク口応 力こう配下のミクロ芯力解析を行った。提案手法は 種々の不均質体の設計・評価に有用であると考光る。

な抢，本研究は経済産業省産業技術環境局が推進す る「シナジ一セラミックス」プロジェクトの一環とし て行われたものである。また，成果の一部は科学研究 費基礎研究 (B) (課題番号 14350058)の補助を受けて 実施したものである。

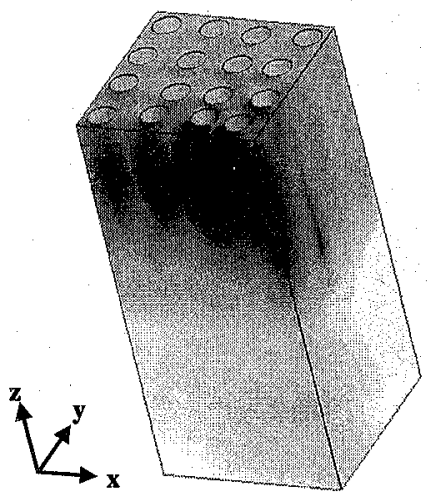

(MPa)

600

540

480

420

360

300

Fig. 12 Analyzed microscopic stress

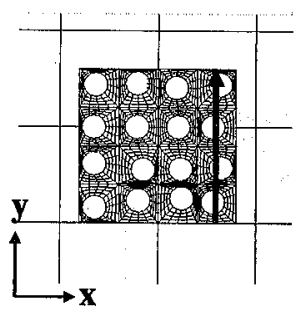

(a) Observed position

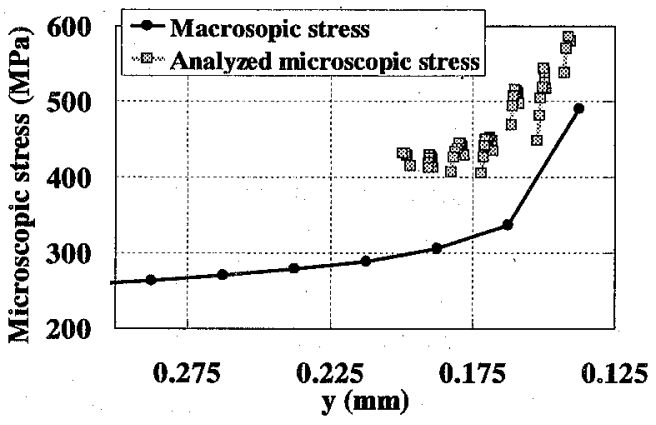

(b) Comparison between micro- and macroscopic stresses

Fig. 13 Microscopic stress under high gradient of macroscopic stress at crack tip 
付録 拡張された重合メッシュ法の 定式化

熱弾性問題に対し，拡張された重合メッシュ法によ り最終的に得られる剛性方程式(11)の各項の計算 式(11)を以下に示す.

$$
\begin{aligned}
& \boldsymbol{K}^{G}=\int_{\Omega^{G}}\left(\boldsymbol{B}^{G}\right)^{T} \boldsymbol{E}^{G} \boldsymbol{B}^{G} d \Omega^{G}+\int_{\Omega^{L}}\left(\boldsymbol{B}^{G}\right)^{T} \boldsymbol{E}^{L} \boldsymbol{B}^{G} d \Omega^{L} \\
& \boldsymbol{K}^{G L}=\int_{\Omega^{L}}\left(\boldsymbol{B}^{G}\right)^{T} \boldsymbol{E}^{L} \boldsymbol{B}^{L} d \Omega^{L} \\
& \boldsymbol{K}^{L}=\int_{\Omega^{L}}\left(\boldsymbol{B}^{L}\right)^{T} \boldsymbol{E}^{L} \boldsymbol{B}^{L} d \Omega^{L} \\
& \boldsymbol{F}=\boldsymbol{F}_{P}^{G}+\boldsymbol{F}_{T}^{G} \\
& \boldsymbol{F}_{P}^{G}=\int_{\Gamma_{p}}\left(\boldsymbol{N}^{G}\right)^{T} \boldsymbol{p} d \Gamma_{p} \\
& \boldsymbol{F}_{T}^{G}=\int_{\Omega^{G}}\left(\boldsymbol{B}^{G}\right)^{T} \boldsymbol{E}^{G} \alpha^{G} \Delta T^{G} d \Omega^{G} \\
& +\int_{\Omega^{L}}\left(\boldsymbol{B}^{G}\right)^{T} \boldsymbol{E}^{L} \alpha^{L}\left(\Delta T^{G}+\Delta T^{L}\right) d \Omega^{L} \\
& \boldsymbol{F}^{L}=\int_{\Omega^{L}}\left(\boldsymbol{B}^{L}\right)^{T} \boldsymbol{E}^{L} \alpha^{L}\left(\Delta T^{G}+\Delta T^{L}\right) d \Omega^{L}
\end{aligned}
$$

\section{文献}

(1) シナジーセラミックス研究体編, “シナジーセラミック ス”, (2000)，2，技報堂出版.

(2) Lions, J. L., Some methods in the mathematical analysis of systems and their control, (1981), 1, Science Press.

(3) Guedes, J. M. and Kikuchi, N., Comput. Methods Appl. Mech. Eng., 83-2 (1990), 143-198.

(4) Terada, K. and Kikuchi, N., Comput. Methods Appl. Mech. Eng., 190-40, 41 (2001), 5427-5464.

(5) 高野直樹 - 柏木有希雄 - 大西慶弘 - 座古勝, 機論, 65-631, A (1999), 498-505.
(6) Takano, N., Uetsuji, Y., Kashiwagi, Y. and Zako, M., Modelling Simul. Mater. Sci. Eng., 7-2 (1999), 207-231.

（7）永井学志・山田貴博・和田章, 日本建築学会構造系論文 集, 509 (1998), 77-82.

（8）高野直樹 - 大西慶弘 - 西藪和明 - 座古勝, 材料, $50-5$ (2001)，461-467.

（9）高野直樹・ 木村圭一・座古勝 - 久保太, 機論, 68-672, A (2002), 1163-1169.

(10) 高野直樹 - 座古勝 - 石園学, 機論, 66-642, A (2000), 220226.

（11）高野直樹 - 座古勝 - 奥野義紘，材料，52-8（2003），952957.

(12) Fish, J., Shek, K., Pandheeradi, M. and Shephard, M. S., Comput. Methods Appl. Mech. Eng., 148-1, 2 (1997), 53-73.

(13) Lee, K., Moorthy, S. and Ghosh, S., Comput. Methods Appl. Mech. Eng., 172-1-4 (1999), 175-201.

(14) Takano, N., Ohnisi, Y., Zako, M. and Nishiyabu, K., Int. J. Solids Struct., 37-44 (2000), 6517-6535.

(15) Fish, J., Comput. Struct., 43-3 (1992), 539-547.

(16) Rashid, M. M., Comput. Methods Appl. Mech. Eng., 154-1, 2 (1998), 133-150.

（17）鈴木克幸 - 大坪英臣・閔勝載・白石卓士郎，日本計算工 学会論文集, 1 (1999), 155-160.

（18）岡田裕 - 遠藤明香 - 菊池正紀, 計算工学講演会論文集, 7$2(2002-5), 517-520$.

(19) Takano, N., Zako, M. and Okazaki, T., JSME Int. J., Ser. A, 44-4 (2001), 602-609.

(20) Takano, N., Zako, M. and Okazaki, T., Proc. 7th Jpn. Int. SAMPE Sympo., (2001-11), 725-728.

（21）溙村太亮・鈴木克幸・大坪英臣 - 中住昭吾, 計算工学講 演会論文集, 8-1 (2003-5), 227-230.

(22）岡田裕・二ノ宮崇・逆瀬川陽介・福井泰好・熊澤典良, 計算工学講演会論文集, 8-1 (2003-5), 243-246.

（23）榛村太亮・鈴木克幸 - 中住昭吾 - 大坪英臣, 計算工学講 演会論文集, 7-2 (2002-5), 529-532.

（24）村田健郎・小国力・唐木幸比古, “ス一パーコンピュー 夕”, (1985), 116-119, 133-135, 丸善. 